Article VII.-The president shall have the power to decide what business may be transacted by correspondence between meetings of the Council.

Article VIII.-The aim of the Council shall be to arrange for the issue of a new edition of the Index Ophthalmologicus at each international congress at a price or prices to be determined from time to time by the Council.

Article IX.-The Secretary of the Council shall supply the delegates with copies of the minutes of the meetings of the Council and the Federation.

Article $X$.-Amendments and additions to these statutes shall be valid only if they are recommended at least 6 months in advance by the International Council (a majority of two-thirds in that body being necessary) or by four delegates of the Federation whose appointments have been confirmed to the Secretary of the Council as in Article III, and if they are accepted by a majority of two-thirds at the joint meeting of the Council and Federation. Such amendments shall be distributed 5 months in advance to the delegates.

\title{
XVII International Congress of Ophthalmology, 1954
}

From the ceremonial opening at the University of Montreal on September 10 to the closing ceremony in the Grand Ballroom of the Waldorf-Astoria Hotel, New York, on September 17, the days passed in far too rapid succession. Indeed the congress was so rich in scientific material that a whole month would hardly have enabled any one to survey all the worthwhile contributions. Moreover this congress was preceded by a scientific meeting of the Canadian Ophthalmological Society in Montreal on September 9, and was followed by the 59th Annual Session of the American Academy of Ophthalmology and Otolaryngology in New York. Many of the congressists were pleased to avail themselves of the useful sequence, which gave them a whole fortnight of meetings.

Dr. Bernard Samuels of New York, who presided over the congress, welcomed the delegates. At this opening ceremony the Gonin Medal was presented to Sir Stewart DukeElder in recognition of his outstanding services to ophthalmology. Sir Stewart then gave a stimulating address as President of the International Council of Ophthalmology. Representatives from each continent also spoke.

Since more than 200 papers were delivered, it was impossible to hear them all. During many of the sessions papers were being simultaneously given in three different rooms. Then again, there were innumerable other items competing for attention, e.g., scientific and technical exhibits, cinema demonstrations, and televised surgical clinics. These telecasts upon a giant $4 \frac{1}{2}$ by $6 \mathrm{ft}$ screen proved to be one of the most popular features of the congress, because the technique of presentation has been so enormously improved.

At the meetings of September 10 and 11, which were held in the Physical Sciences Centre of McGill University, Montreal, panel discussions were devoted to Retrolental Fibroplasia and to Virus Diseases of the Eye. Other papers were delivered on various subjects, and one session was allotted to the International Organization against Trachoma.

On September 12, the eve of the Reopening Assembly in New York, Dr. Ida Mann gave a fascinating illustrated lecture describing her recent survey of aboriginal and other inhabitants of the Kimberley region, in the north-west of Western Australia. Congressists were also privileged to hear an inspiring speech by Miss Helen Keller, who was the chief guest at a dinner during the congress. The New York sessions were held in the WaldorfAstoria Hotel. Chief discussion subjects were Primary Glaucoma and the Aetiology of Uveitis, but other papers ranged over the whole field of ophthalmology. Several orthoptic 
demonstrations were staged, and a symposium on Strabismus Surgery and Orthoptics took place on September 19, the eve of the Academy meetings. Those who remained for the Academy session were able to hear Dr. Algernon B. Reese deliver the Jackson Memorial Lecture on Persistent Hyperplastic Primary Vitreous.

Fifty-four nations were represented at the XVII International Congress of Ophthalmology, and it goes without saying that their reception entailed a vast amount of planning. This short article cannot do justice to the kindly forethought of our hosts in Montreal and New York, but it must be emphasized that everything conceivable was done to make a happy background. In addition to the carefully planned scientific programme there were outings and indoor entertainments for wives and other associate members. All these arrangements were supplemented by generous private hospitality in both cities, so that every member of the congress will look back with joy to September, 1954. Dr. Bernard Samuels and his helpers in Canada and in the U.S.A. are to be congratulated upon the outcome of their splendid planning.

\title{
Ophthalmological Society of New South Wales
}

\section{Norman McAlister Gregg Triennial Prize}

The following are the conditions applicable to the Norman McAlister Gregg Triennial Prize established by the Ophthalmological Society of New South Wales for a work on an ophthalmological subject.

1. The Ophthalmological Society of N.S.W. will every three years award a prize of 100 guineas (Aust.) and a bronze medallion for a work on an ophthalmological subject.

2. The prize will be awarded to the candidate whose work is deemed to be the most valuable contribution to knowledge in ophthalmology.

3. Entries for the prize competition will be received from any British subject. Entries will close for the present prize on August 31, 1955, at midday.

4. The work submitted must be in the English language. The work must be original and if such work has been submitted previously for publication details must be supplied by the candidate.

5. Examiners shall be appointed for the competition by the Council of the Society and the Council's decision as to the winning entry shall be final and conclusive. If the Council is of the opinion that no work is of sufficient merit it shall not award the prize.

6. Intending candidates shall notify the secretary of the society of their intention to submit contributions at least 2 months before the closing date.

7. Three copies of the work are to be submitted, typewritten and double-spaced. Each work shall bear a motto and shall be accompanied by a sealed envelope containing the author's name and qualifications.

\author{
E. J. Donaldson (Secretary), \\ 229, Macquarie St., \\ Sydney, N.S.W., Australia.
}

\section{All India Ophthalmological Conference}

\section{Bombay, 1955}

A CORDIAL invitation is extended to all members of the Ophthalmological Society of the United Kingdom to attend this conference, which is to take place in the first week of March, 1955. A programme of general and scientific interest is being prepared. The chief item will be a symposium on "Diseases of the Lacrimal Apparatus". Further information may be obtained from the Secretary of the Conference:

Dr. V. V. Gupta, 19, Pherozshah Mehta Road, Bombay, 1. 